\title{
Study on Significant Mechanisms of Maintenance Culture Among Public Building Users in Malaysia
}

\author{
Ezzatul Aifa Binti Rusli ${ }^{1}$, Md Azree Othuman Mydin²,a ${ }^{2}$ Shardy Abdullah ${ }^{3}$, \\ ${ }^{1,2,3}$ School of Housing, Building and Planning, Universiti Sains Malaysia, 11800, Penang, Malaysia
}

\begin{abstract}
Malaysia, a country in Asia, is a fast-growing developing country in its construction so as to fulfil the demands of today. Many buildings, infrastructures and facilities were constructed; however, the necessary support required after construction was disregarded. Maintenance is the key for the system, and culture is the main point of attitude and behaviour towards the maintenance culture. Becoming one of the first class infrastructures in the world is the vision that Malaysia is striving to achieve, and a third mentality from society and organisations should be avoided. However, to achieve this vision, proper maintenance is not enough; a maintenance culture should be applied. Developing a maintenance culture will help obtain the vision quickly and increase the quality of productivity in maintenance. It will also reduce the repair cost and increase responsibility. Malaysia is becoming a first class infrastructure, which is the vision for today; therefore, it needs to avoid a third mentality. Concerning this matter, decisive components of the maintenance culture were studied to identify the types of components that influence the maintenance culture among public building users. The decisive components of maintenance were uncertainty awareness and responsibility; personality/human behaviour and attitude; mind-set/motivation; training; knowledge and learning process; culture trends; management commitment; management of organisation; leadership; fundamental and policy; operating system organisation; the enforcement; laws and rules; and current practice of maintenance methods.
\end{abstract}

\section{Introduction}

The construction of any building, whether by the government or the private sector, is usually based on fulfilling specific needs; either for the use of providing services, investment purposes, occupancy or others within a stipulated period of time. Therefore, the proper maintenance system should be indeed maintained in a good and effective manner. The building should install proper maintenance. Hafizi et al. [1] stated that a building must ensure that it is in a safe and productive state, able to be correctly utilised, fulfils all legal requirements, maintains its physical asset value and upholds its build quality.

The continuance of construction activity required by the government must be provided with efficient services to the public [2]. This is in-line with the statement made by the Malaysian Works Ministry that explained how the increased role and responsibilities of the Federal Agencies at the state level had caused the need for more construction of Federal Buildings at both the state and district

\footnotetext{
a Corresponding author : azree@usm.my
} 
levels. As a consequence, the increase of federal buildings was in tandem with the rise of maintenance cost borne by the government [3].

In the Eighth Malaysian plan, the development plan allocation for repair and maintenance works was RM296 million, which increased to RM11079 million in the Ninth Malaysian plan [4]. This proved that repair and maintenance activity will be become increasingly important in the future. Even though the government allocated very high portions, negative issues are still being reported. Despite the government's commitment towards building maintenance, buildings have not been effectively maintained [5]. It was shown that there was an apparent weakness in the aspect of public buildings. The ineffective implementation of maintenance activities in public buildings was directly associated with cultural aspects where the existing maintenance culture was imperative in providing a world class infrastructure in a nation [6]. The issues of considering maintenance culture aspects are one of the factors that cause maintenance works to be conducted inefficiently

\section{Methodologies}

This study was conducted according to the secondary data, whether the data review involved published or unpublished data such as journals, books, theses, articles and conferences. From this secondary data, the decisive component maintenance culture was discovered. The theoretical framework for this study was developed, as well as the questionnaire form to be used for research data collection. A purposive sampling method was chosen which involved eight federal buildings located in Penang, Selangor, Terengganu and Melaka. A total of 350 sets of the questionnaires were distributed and $51.1 \%$ were received from respondents. This study employed a questionnaire instrument that consisted of four sections: Section A (demographic respondents), Section B (importance of maintenance culture), Section C (critical component maintenance culture) and Section D (component influence of maintenance culture among public building users). The sampling used a 5point Likert Scale (no neutral choice) with a light sense of force, ranging from 1 "Strongly Disagree," 2 "Disagree," 3 "Not Sure," 4 "Agree" and 5 "Strongly Agree" as to measure the respondents' choice of maintenance culture. The Likert Scale was used in Section B, Section C and Section D. The SSPS 2.0 software was applied to analyse the data. The Cronbach's Alpha reliability test was carried out to determine the reliability of the responses obtained for each of the maintenance culture components that were listed in the questionnaire. Moreover, Nunnally (1978) recommended that instruments used in basic research have a reliability of about 0.7 or higher. In this study, five top components were chosen based on Cronbach's Alpha analysis which was over 0.950, and this was due to the strong components that formed the maintenance culture.

\section{Data Analysis and Discussions}

A total of 179 questionnaires were collected. A total of 103 of the respondents were female $(57.54 \%)$ and only $76(42.46 \%)$ were male. The largest age group of respondents were within the age of 31 to 40 years old $(37.75 \%)$, followed by the age group of 26 to 30 years old $(33.52 \%), 41$ to 60 years old $(22.35 \%)$ and finally the age group of 18 to 25 years old $(8.4 \%)$. The majority of the respondents were Malay (91.06\%) and the minority of the respondents were Other Race. Both Indian and Chinese had the same value which was $3.4 \%$. Most of the respondents had 1 to 5 years of experience $(41.9 \%)$ in the organisation, followed by respondents who had 5 to 10 years of experience $(20.1 \%)$ and then those with more than 10 years of experience $(26.3 \%)$. Only $11.7 \%$ of the respondents had less than 1 year of experience in the organisation. The majority of respondents had no experience in maintenance $(64.8 \%)$ while only $35.2 \%$ had experience in maintenance. From the respondents $(35.2 \%)$ who had experience in maintenance, the majority had 1 to 5 years $(54.10 \%)$ of experience, followed by the respondents who had experiences in maintenance from 6 to 10 years $(24.6 \%)$ and then by those with more than 16 years of experience $(19.67 \%)$. Only $(1.64 \%)$ of the respondents had 11-15 years of experience in maintenance. 
Table 1. Cronbach's Alpha of Importance of Maintenance Culture and Components

\begin{tabular}{|l|c|c|c|}
\hline \multicolumn{1}{|c|}{ Variable } & $\begin{array}{c}\text { Cronbach's } \\
\text { Alpha }\end{array}$ & Ranking & $\begin{array}{c}\text { No of } \\
\text { Questions }\end{array}$ \\
\hline Importance of Maintenance Culture & 0.879 & & 5 \\
\hline Critical Component & 0.871 & - & 16 \\
\hline Components Influence Maintenance Culture & & & \\
1. Awareness & $\mathbf{0 . 9 5 2}$ & $\mathbf{5}$ & $\mathbf{4}$ \\
2. Responsibility & $\mathbf{0 . 9 5 9}$ & $\mathbf{1}$ & $\mathbf{4}$ \\
3. Personality and attitude & 0.931 & 11 & 4 \\
4. Mind-set & 0.881 & 16 & 4 \\
5. Motivation & 0.917 & 14 & 4 \\
6. Knowledge & $\mathbf{0 . 9 5 5}$ & $\mathbf{3}$ & $\mathbf{4}$ \\
7. Training & $\mathbf{0 . 9 5 4}$ & $\mathbf{4}$ & $\mathbf{4}$ \\
8. Culture Trend & 0.918 & 13 & 4 \\
9. Leadership & 0.905 & 15 & 4 \\
10. Management Commitment & 0.940 & 8 & 4 \\
11. Management Of Organisation & 0.941 & 7 & 4 \\
12. Fundamental and Policy & 0.938 & 9 & 4 \\
13. Operating System Organisation & 0.930 & 12 & 4 \\
14. The Enforcement & 0.945 & 6 & 4 \\
15. Laws and Rules & $\mathbf{0 . 9 5 9}$ & $\mathbf{1}$ & $\mathbf{4}$ \\
16. A Practice of Current Method of Maintenance & 0.936 & 10 & 4 \\
\hline
\end{tabular}

Table 1 displayed the results of the maintenance culture components in 8 federal buildings. It was agreed by the respondents that the maintenance culture components were important and it influences public building users. The components were high with the Cronbach's Alpha for importance of maintenance culture and critical component amounting to 0.879 and 0.871 . The Cronbach's Alpha for components influencing maintenance culture was 16 components and the highest were responsibility and laws and rules which were 0.959 . This was followed by knowledge (0.955), training (0.954) and awareness (0.952). Next was enforcement (0.945), management of organisation (0.941), management commitment (0.940) and fundamental and policy (0.938). The next value of Cronbach's Alpha was current practice method of maintenance (0.936), personality and attitude (0.931), operating system organisation (0.930), culture trend (0.918) and leadership (0.905). The lowest value was mind-set (0.881).

Table 2. The Component of Responsibility

\begin{tabular}{|c|l|c|c|}
\hline No & \multicolumn{1}{|c|}{ Item } & $\begin{array}{c}\text { Cronbach's Alpha if } \\
\text { Item Deleted }\end{array}$ & Mean \\
\hline $\mathbf{1}$ & $\begin{array}{l}\text { Responsibility is important for the performance of maintenance } \\
\text { activities that aim to maintain assets, infrastructure and facilities. }\end{array}$ & 0.947 & 4.4134 \\
\hline $\mathbf{2}$ & $\begin{array}{l}\text { Good responsibility is to acknowledge and perform maintenance } \\
\text { activity with the best work. }\end{array}$ & 0.947 & 4.3631 \\
\hline $\mathbf{3}$ & $\begin{array}{l}\text { Responsibility establishes positive attitudes towards maintenance } \\
\text { culture. }\end{array}$ & 0.942 & 4.3855 \\
\hline $\mathbf{4}$ & $\begin{array}{l}\text { Responsibility establishes curiosity and concern to maintain a } \\
\text { public building. }\end{array}$ & 0.949 & 4.3520 \\
\hline Cronbach's Alpha : 0.959 & & \\
\hline
\end{tabular}

The results of the study supported the results of past studies and found that maintenance culture was important and acceptable with 16 components. The most important maintenance culture components were responsibility [7] and laws and rules that need to be followed by users. In this paper, only five top components presented the questions, mean and Cronbach's Alpha if item was deleted. Cronbach's alpha for these five components was over 0.950 and it was the highest in this study. 
Table 3. The Components of Rules and Laws

\begin{tabular}{|c|l|c|c|}
\hline No & \multicolumn{1}{|c|}{ Item } & $\begin{array}{c}\text { Cronbach's Alpha if } \\
\text { Item Deleted }\end{array}$ & Mean \\
\hline $\mathbf{1}$ & $\begin{array}{l}\text { Rules and laws of maintenance are maintenance guidelines to } \\
\text { achieve the standard. }\end{array}$ & 0.945 & 4.2905 \\
\hline $\mathbf{2}$ & $\begin{array}{l}\text { Rules and laws prescribed maintenance to be important for } \\
\text { achieving compliance with government standards. }\end{array}$ & 0.946 & 4.2961 \\
\hline $\mathbf{3}$ & $\begin{array}{l}\text { Rules and laws are important to maintain the building and } \\
\text { maintenance culture in a long-term period. }\end{array}$ & 0.945 & 4.3128 \\
\hline $\mathbf{4}$ & $\begin{array}{l}\text { Rules and laws can reduce repair cost, improve the quality of the } \\
\text { building and create excellent maintenance culture. }\end{array}$ & 0.950 & 4.3184 \\
\hline Cronbach's Alpha : 0.959
\end{tabular}

The most important maintenance culture components were responsibility (Table 2) and laws and rules (Table 3), as previously mentioned. Responsibility was an important role and a cornerstone for both individuals and organisations regarding the duties given by organisations. In any case, the feeling of professional pride and the sense of meaningfulness of one's own work was a very positive aspect for the maintenance culture: possessing experience and responsibility were the central aspects emphasised in the artefacts (management talks, procedures, etc.) of the culture [7] and this was proven by the value of the mean (4.3855). Rules and laws were the guidelines for maintenance system that users must follow to achieve government standards; illustrating the importance of maintenance culture (4.3184).

Table 4. The Components of Knowledge

\begin{tabular}{|c|c|c|c|}
\hline No & Item & $\begin{array}{l}\text { Cronbach's Alpha if } \\
\text { Item Deleted }\end{array}$ & Mean \\
\hline 1 & $\begin{array}{l}\text { Knowledge in maintenance is increasingly important for achieving } \\
\text { higher productivities in maintenance managements. }\end{array}$ & 0.941 & 4.3575 \\
\hline 2 & $\begin{array}{l}\text { Knowledge is in an accelerating pace of change in the business } \\
\text { environment, such as in the maintenance culture. }\end{array}$ & 0.943 & 4.3240 \\
\hline 3 & Having knowledge can reduce the load of management. & 0.939 & 4.3520 \\
\hline 4 & $\begin{array}{l}\text { Knowledge is helpful and worthy in managing maintenance } \\
\text { activities. }\end{array}$ & 0.940 & 4.3743 \\
\hline \multicolumn{4}{|c|}{ Cronbach's Alpha : 0.955} \\
\hline
\end{tabular}

Table 4 displayed the components of knowledge, which was third in rank. Knowledge is the process involved in establishing and implementing programs that provides benefit for those involved in enforcing them [8] and it is useful in managing maintenance activity (mean value: 4.3743). Knowledge is of increasing importance for achieving higher productivity and is on an accelerating pace of change in the business environment.

Table 5 The Component of Training

\begin{tabular}{|c|l|c|c|}
\hline No & \multicolumn{1}{|c|}{ Item } & $\begin{array}{c}\text { Cronbach's Alpha if } \\
\text { Item Deleted }\end{array}$ & Mean \\
\hline $\mathbf{1}$ & $\begin{array}{l}\text { Training is the development of attitudes, knowledge and specialised } \\
\text { skills in maintenance activities. }\end{array}$ & 0.953 & 4.3520 \\
\hline $\mathbf{2}$ & $\begin{array}{l}\text { Exercise is essential to the performance of the job properly and } \\
\text { improving the quality of the tasks. }\end{array}$ & 0.942 & 4.3520 \\
\hline $\mathbf{3}$ & $\begin{array}{l}\text { Regular exercise gives good practice and may demonstrate an } \\
\text { individual's skills or knowledge for improvement in the culture of } \\
\text { maintenance. }\end{array}$ & 0.927 & 4.3464 \\
\hline $\mathbf{4}$ & $\begin{array}{l}\text { Training creates higher awareness to ensure that the assets and } \\
\text { facilities are in the safe zone. }\end{array}$ & 0.934 & 4.3128 \\
\hline Cronbach's Alpha : 0.954 & & \\
\hline
\end{tabular}


Table 5 showed the components of training which was fourth in rank. Training is the development of attitudes, knowledge and specialised skills required by the employees to perform their duties properly [9]. This was proven by the value of the mean (4.3520). Training also provides regular practice in actions which may form into habits that will lead to skills or knowledge; improving individuals (mean value: 4.3520). Through this, individuals and groups will have the awareness to keep assets and facilities, and may also have the desire to improve the quality of work during job performance.

Table 6. The Components of Awareness

\begin{tabular}{|c|l|c|c|}
\hline $\mathbf{N o}$ & \multicolumn{1}{|c|}{ Item } & $\begin{array}{c}\text { Cronbach's Alpha if } \\
\text { Item Deleted }\end{array}$ & Mean \\
\hline $\mathbf{1}$ & Awareness is needed as a basis for the culture of maintenance. & 0.808 & 4.3296 \\
\hline $\mathbf{2}$ & $\begin{array}{l}\text { Awareness is established among user's willingness to develop } \\
\text { the maintenance culture of public buildings. }\end{array}$ & 0.833 & 4.2849 \\
\hline $\mathbf{3}$ & $\begin{array}{l}\text { Awareness will create a sense of responsibility to improve the } \\
\text { performance of the maintenance program. }\end{array}$ & 0.814 & 4.3073 \\
\hline $\mathbf{4}$ & $\begin{array}{l}\text { Awareness will create a desire for change in developing a } \\
\text { better maintenance environment. }\end{array}$ & 0.818 \\
\hline Cronbach's Alpha : 0.952 & & 4.3184 \\
\hline
\end{tabular}

Lack of uncertainty awareness will negatively affect the culture and that may also influence the next generation of that culture. Table 6 presented respondents' agreement on 'awareness' being the top five that influence maintenance culture. The respondents acknowledged that awareness is the basis for a culture of maintenance, proven by the value of the mean (4.326) which was the highest. This was mentioned by Suwaibatul et. al [10] whereby our culture failed to learn their lessons that every year the audit report displayed the increasing cost for maintaining government assets $[11,12,13]$.

In summary (Table 7), the following were the most significant components that influence maintenance culture among public building users, as ranked by the respondents.

Table 7. Top Five Hypotheses on the Components of Maintenance Culture

\begin{tabular}{|l|l|}
\hline Component & \multicolumn{1}{|c|}{ Description } \\
\hline Responsibility & $\begin{array}{l}\text { Responsibility is an important role and a cornerstone for both individuals and organisations } \\
\text { regarding duties given by organisations, which showed positive aspects on individuals and } \\
\text { their duties. }\end{array}$ \\
\hline $\begin{array}{l}\text { Rules and } \\
\text { laws }\end{array}$ & $\begin{array}{l}\text { Rules and laws are the guidelines for the maintenance system that users must follow to achieve } \\
\text { government standards. }\end{array}$ \\
\hline Knowledge & $\begin{array}{l}\text { Knowledge is the process involved in establishing and implementing such programs that } \\
\text { provide benefit for those who implement them. }\end{array}$ \\
\hline Training & $\begin{array}{l}\text { Training is the development of attitudes, knowledge and specialised skills required by the } \\
\text { employees to perform their duties properly. Training is also the regular practice of actions } \\
\text { which become habits that show improved skills or knowledge. }\end{array}$ \\
\hline Awareness & $\begin{array}{l}\text { Lack of uncertainty awareness will effect negatively and may influence the culture and the } \\
\text { next generations of cultures. }\end{array}$ \\
\hline
\end{tabular}

The outcome of this paper was to determine the decisive components which influence the existence of a maintenance culture of public building users, and to investigate the manner and form of these decisive components. The results presented the top five components that were much stronger than the other components. However, the other components were also 'acceptable' since the results illustrated that the Cronbach's Alpha analysis was more than 0.7 (Nunnally, 1978). To form the maintenance culture into any organisation, all these components are needed. 


\section{Conclusion}

Overall, the results of this study designated that the maintenance culture components are very important. The conclusion can be used as a basis to develop maintenance culture in the maintenance industry in Malaysia for the relevant public building users. Maintenance culture needs to be developed and applied in public sectors as well as private ones. It is hoped that these findings would become a catalyst for a more compressive study. To provide stronger evidence and analysis for the adequacy of the result, future research is suggested to examine larger samples involving all public buildings in Malaysia (including all federal buildings, public facilities, universities, schools, army bases, police stations and so on). This study can also be applied in the private sector. Both public and private sectors can employ this study since it may give numerous benefits and ensure that users are aware of building environments. It is useful to guarantee that users have high productivity, save cost and high quality and thus can intensify the image of the organisation in the world and spread the information plan set by the government; obtaining the title of 'first world infrastructure and first world mentality'.

\section{Acknowledgement}

The authors would like to thank the funding bodies of this research; Universiti Sains Malaysia under USM RU Grant. No. 1001 / PPBGN / 816231.

\section{References}

1. Hafizi Zakaria, Kadir Arifin, Shaharuddin Ahmad, Kadaruddin Aiyub and Zahedi, Pengurusan Fasiliti Dalam Penyelenggaraan Bangunan :Amalan Kualiti, Keselamatan Dan Kesihatan ,Journal Of Techno-Social .

2. Azlan Shah Ali, 2009, Cost decision making in building maintenance practice in Malaysia, Journal of Facilities Management, Vol. 7 (4): 298 - 306.

3. Suwaibatul Islamiah Abdullah Sani, 2011. Abdul Hakim Mohammed, Fatin Syazwina Abdul Shukor, Mariah Awang. Development of Maintenance Culture: A Conceptual Framework, 2011. International Conference On Management (ICM2011) Proceeding.

4. Prince Jude Cobbinah, Maintenance Of Buildings Of Public Institutions In Ghana, Case Study Of Selected Institutions In The Ashanti Region Of Ghana, 2010.

5. Harry C. Triandis and Eunkook M.Suh Culture Influences On Personality, 2002

6. Mark C.Eti, S.O.T. Ogaji And S. D Probert, Strategic Maintenance-Management In Nigerian Industries , 2006

7. Teemu Reiman, Pia Oedewald, Jari Kettunen, Carl Rollenhagen, Ulf Kahlbom, VTT Industrial Systems , Mälardalen University, Maintenance Culture And Management Of Change Intermediate Report 2004

9. Suwaibatul Islamiah Abdullah Sani, Abd Hakim Mohammed, Fatin Syazwina Abdul Sukor And 'Eizzatul' Ain S. Improvement Maintenance Work Through Adopting A Maintenance Culture: Focused The Determinant Factor Which Influence Maintenanace Culture, 2012. 3rd International Conference on Business and Economic Research 3rd ICBER 2012 Proceeding.

10. Suwaibatul Islamiah Abdullah Sani, Abdul Hakim Mohammed, Mohd Siadin Misnan, Mariah Awang, Determinant Factors In Development Of Maintenance Culture In Managing Public Asset And Facilities, International Congress On Interdisciplinary Business And Social Science, 2012.

11. Adelakun Adebiyi Alani. Maintenance Culture A Threat To Educational Accessibility In Nigeria : Implications For Sustainable Open Distance Learning In Nigeria, 2012)

12. Gary Yukl, Leadership in Organizations (5th Edition), 2001, Prentice Hall. 